\title{
Total Phenolic Content of Ethanol Extract of Artrocarpus camansi Leave and its Effect to SOD (Superoxide Dismutase) Level in Mice
}

\author{
Hendri Asrin, Poppy Anjelisa Zaitun Hasibuan*, Marianne \\ Department of Pharmacology, Faculty of Pharmacy, University of Sumatera Utara, Medan, Indonesia
}

\begin{abstract}
A free radical is one of the triggers of degenerative diseases that become the biggest cause of death. Excessive production of free radicals can be neutralized by antioxidant. Antioxidants can be generated from within the body (intracellular). One of them by the enzyme SOD (superoxide dismutase). However, when the production of free radicals exceeds the ability of intracellular antioxidants to neutralize it, antioxidants from outside (extracellular) is necessary. The ethanol extract of Artocarpus camansi leaves (EEACL) contains phenolic compounds which has very strong antioxidant activity based on in vitro study using the DPPH method, but the in vivo study about the total phenolic content effect of its leaves toward antioxidant activity has not been done. 25 mice were divided into 5 groups consisting of control group, a group was induced by stress and three groups were induced by stress, but given EEACL with each dose of $50 \mathrm{mg} / \mathrm{kg}$ bw, $100 \mathrm{mg} / \mathrm{kg}$ bw and $150 \mathrm{mg} / \mathrm{kg}$ bw. Inducing stress in the form of psychological stress was carried out for 7 days and continued with the EEACL administration for 7 days. The mice were dissected and the livers were isolated, then the liver morphological was examined using Hematoxyllin Eosin (HE) staining method and SOD level was examined with immunohistochemical staining method. The data were analyzed with One Way ANOVA and Duncan test using SPSS program version 19.0. Total phenolic content of EEACL is $235.03 \pm 4.306$ $\mathrm{mg} \mathrm{GAE} / \mathrm{g}$ of sample. The average SOD levels in the control group is $94.05 \%$, stressed group is $55.94 \%$, stress with EEACL dose $50 \mathrm{mg} / \mathrm{kg}$ bw group is $58.40 \%$, stress with EEACL dose 100 $\mathrm{mg} / \mathrm{kg}$ bw group is $79.68 \%$, stress with EEACL dose $150 \mathrm{mg} / \mathrm{kg}$ bw group is $80.90 \%$. Based on statistical result, SOD level increased along with the increase of EEACL dose, but not significantly $(p<0,05)$. Total phenolic content of EEACL has an influence to SOD levels. SOD level increased along with the increase of EEACL administration dose. The higher dose of EEACL leading to higher levels of SOD in the mouse liver.
\end{abstract}

Keywords: total phenolic content, superoxide dismutase, antioxidant, Artocarpus camansi

\section{INTRODUCTION}

Chronic disease is a biggest cause of death in nearly all countries. $60 \%$ of global death cases is caused by chronic disease as well as degenerative diseases such as cardiovascular disease, cancer, chronic respiratory diseases and diabetes (Anisman and Merali,1999). The main contributor of these diseases is unhealthy lifestyle such as smoking, drinking alcohol, unhealthy diet and obesity, lack of physical activity, stress and pollution (Chida, et al., 2006).

One of triggers of degenerative disease is stress. Some of researchers show that phsycological stress can increase the free radical production as Reactive Oxygen Species
(ROS) (Nishio, et al., 2007). Free radicals are not neutralized will cause cell damage as a cause of several disease that appear because of the reaction between free radicals with cell components such as enzym, lipid, DNA and carbohydrate (Halliwell, 2001).

Antioxidant is a substance to neutralized free radicals. It can avoid oxidative reaction by giving its electron to free radical molecule resulting in breaking of the chain reaction caused by free radical. The body has three of intracell antioxidant enzyme or endogenous antioxidant, namely Superoxide dismutase (SOD), Glutation peroxidase (GPx) dan Catalase (Cat).

*Corresponding author e-mail: poppyanjelisa@usu.ac.id 
SOD is one of endogenous antioxidant to catalyse dismutation reaction of superoxide anion $\left(\mathrm{O}^{-}\right)$into hydrogen peroxide and oxygen (Halliwell, 2006). If the free radicals production exceed the capacity of intracell antioxidant to neutralize it, it will be potential to cause cell demage (Kevin, et.al., 2006). In this condition, the external antioxidant is necessary.

The external antioxidant source can be natural and syntetic antioxidant. But recently, natural antioxidant use is more popular because it is more secure than the syntetic antioxidant (Pieta, 2000). It also popular because it widely use in food preservation, health and cosmetics. One of natural antioxidant is phenolic compounds. The phenolic antioxidant is a potential antioxidant. It is a subtance which can give a hidrogen to free radical and break of lipid oxidation reaction chain in initiation phase (Gulcin, et al., 2004).

One of the plants that contain phenolic compounds is Artocarpus camansi. The simplisia and ethanol extract of kluwih's leaves has alkaloids, flavonoids, tannins, glycoside, antraquinone and steroids/triterpenoids (Marianne, et al., 2011). The ethanol extract of kluwih's leaves has very strong antioxidat activity known by $\mathrm{IC}_{50}$ value of $38.65 \mu \mathrm{g} / \mathrm{mL}$ in antioxidant study with $\mathrm{DPPH}$, but in vivo data about its antioxidant activity has not found yet. By in vivo, antioxidant activity can be carried out by measure SOD level as an antioxidant in the body.

\section{METHODOLOGY}

\section{Tools and Instruments}

Vortex

(Boeco

germany),

spectrophotometer UV-Visible 1200 (Shimadzu), microscope (Boeco germany).

\section{Materials}

Sodium CMC, Folin-Ciocalteu reagen, aquabidest, gallic acid, sodium carbonate, formaldehide solution 10\%, ethanol, Tris Buffered Saline pH 7,4, xylol, Dako Epitop Retrieval, peroxide block, Normal Horse Serum (NHS) 3\%, Dako Real Envision Rabbit/Mouse,
DAB (3,3-diaminobenzidine etrahydrochloride), hemotoxylin, eosin, lithium carbonat.

\section{Extract Preparation}

The extract preparation was done by percolation method. 500 grams of simplisia powder was macerated with ethanol $96 \%$ for 3 hours. Then, it was moved to percolator gradually. Add the ethanol $96 \%$ until it submerged with a layer of solution on it and the percolator was closed and saved for 24 hours. After 24 hours, percolator tap was opened and extract solution drop was set for 20 drops per minute. The $96 \%$ ethanol was added continously and set its drop speed same as the percolat to keep simplisia still wet. Percolation then was stopped after the percolat had been clear. The percolat was distillated and evaporated at low pressure with temperature not more than $50^{\circ} \mathrm{C}$ using rotary evaporator, then the thick extract was obtained.

\section{Total phenolic compound examination}

$3 \mathrm{~mL}$ of extract solution of ethanol was blended with $1.5 \mathrm{~mL}$ Folin-ciocalteu reagent $(1: 10)$ in the reaction tube. It was mixed with vortex and saved at room temperature for 5 minutes. $1.5 \mathrm{ml}$ of $\mathrm{Na}_{2} \mathrm{CO}_{3}(7,5 \% \mathrm{~b} / \mathrm{v})$ was inserted into the solution, vortex and incubated at room temperature for 60 minutes. The absorbation was measured by spectrophotometry UV-Vis at $752 \mathrm{~nm}$. The phenolic content of EEKL was calculated by substitute the mean value of sample absorbance to regresion equation which obtained from calibration curve. The total phenolic content was presented in miligrams of gallic acid equivalent per gram of sample (mg GAE/g sample) (Rosidah, et al., 2008).

\section{Animal Treatment}

25 of mice with 30-40 grams weigh, divided into 5 groups and each group consist of 5 mice. It was given difference treatment for each group, namely :

Group 1 : The control group treated normally. Group 2 : The group treated with a psychology stress. 
Group 3 : The group treated with a psychology stress but it was given with EEKL dose $50 \mathrm{mg} / \mathrm{kgbw}$.

Group 4 : The group treated with a psychology stress but it was given with EEKL dose $100 \mathrm{mg} / \mathrm{kgbw}$.

Group 5 : The group treated with a psychology stress but it was given with EEKL dose $150 \mathrm{mg} / \mathrm{kgbw}$.

All of mice was acclimatization for 7 days. Each of cages was given with 5 grams of bedding and feed regularly.

The stress induction was modificated from the study of Nishio, et al. (2007). In the group with stress treatment (Group 2,3,4 and 5 ), each of mouse was isolated each other to avoid social contact among them, but the control group (group 1) was kept treating normally. The bedding volume for each cage with stressed mice also was decreased become $1 / 10$ times of the normal group bedding volume. After 7 days of stress induction, all of mouse in last three groups (group 3,4 and 5) was treated with EEACL orally for 7 days. After one week of extract administration, the mice was sacrified by cervical dislocation and the livers were isolated for examinating of histology by Hematoxylin Eosin and Immunohistochemistry.

\section{RESULTS AND DISCUSSION}

\section{Determination of total phenol content}

The formation of a blue colored complex compounds due to the reaction between phenolic compound with the Folin-Ciocalteu that can be measured at a wavelength of $765 \mathrm{~nm}$. This reagent oxidizes phenolic hydroxyl and reduce heteropoly acid (fosfomolibdatfosfotungstat) contained in the Folin-Ciocalteu reagent into a blue complex of molybdenumtungsten that can be detected with a spectrophotometer. The greater of the concentration of phenolic compounds, the more phenolics ions will reduce heteropoly acid (fosfomolibdat-fosfotungstat) becomes complex of molybdenum-tungsten result in the increasing of blue color concentration. Phenolic compounds react with the Folin-Ciocalteu reagent only under alkaline conditions to enable the dissociation of protons in phenolic compounds into phenolic ions. This alcaline conditions was formed by adding $7.5 \%$ of $\mathrm{Na} 2 \mathrm{CO} 3$ (Rosidah, et al., 2008).

Calibration curve obtained from the relation of various levels of gallic acid with formed absorbance. From this calibration curve, the value of $\mathrm{R} 2$ was obtained.

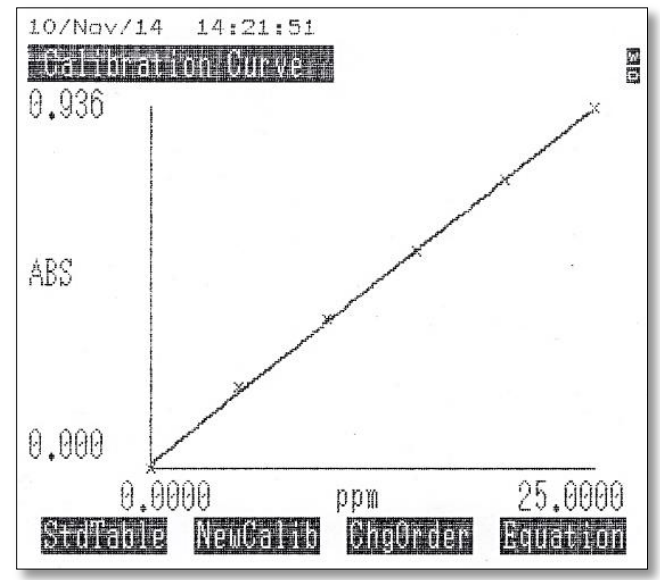

Figure I. Calibration curve of gallic acid

From the calibration curve above (Fig.1), the regression line equation $y=0.036 x+0.013$ with $\mathrm{r} 2=0.9992$. Total phenol content was calculated by substituting the absorbance value (y) of the sample solution in maximum wavelength into the linear regression line equation $y=a x+b$ derived from gallic acid calibration curve to obtain the concentration ( $\mathrm{x}$ ). The value of $x$ and then substituted into the formula to calculate the total phenol content.

$$
\text { Total phenol content }=\frac{\mathrm{x} \text {. V. FP }}{\mathrm{BS}}
$$

Where $\mathrm{x}, \mathrm{V}, \mathrm{FP}$, and $\mathrm{BS}$ are concentration $(\mu \mathrm{g} / \mathrm{ml})$, volume of extract $(\mathrm{ml})$, sample dilution factor, and weight of extract (g), respectively. The results of total phenol content measurements are shown in Table 1. 


\begin{tabular}{|c|c|c|c|c|}
\hline Repetition & $\begin{array}{l}\text { Sample } \\
\text { weight } \\
\text { (gram) }\end{array}$ & Absorbance & $\begin{array}{l}\text { The mean of } \\
\text { absorbance }\end{array}$ & $\begin{array}{l}\text { Total phenol content } \\
\text { (mg GAE/gram of } \\
\text { sample) }\end{array}$ \\
\hline 1 & 0.057 & $\begin{array}{l}0.496 \\
0.501 \\
0.498\end{array}$ & 0.498 & 236.42 \\
\hline 2 & 0.052 & $\begin{array}{l}0.445 \\
0.431 \\
0.448\end{array}$ & $0.44 I$ & 233.09 \\
\hline 3 & 0.054 & $\begin{array}{l}0.470 \\
0.475 \\
0.469\end{array}$ & 0.47 I & 235.59 \\
\hline
\end{tabular}
deviation (SD)

The obtained total phenol content of Artocarpus camansi is quite high $(235.03 \pm 4.306$ mg GAE/gram of extract). Total phenol content are influenced by the type of solvent. Phenol is a polar compound, so the highest solubility in polar solvents. Another extraction factors that contributed to total phenol content are temperature and the duration of extraction. Phenol compounds is susceptible to oxidized at high temperature and the long duration of extraction can give opportunity to phenolic compounds oxidized more. As a result, the measured total phenol content can be lower (Rosidah, et al., 2008).

\section{Liver Histology overview}

Based on the histological examination results of the mice liver, it shows that in the control group, the structure liver tissue in all mice are still in good condition although in some parts there is cells degeneration. Some cells also undergo apoptosis which is characterized by cell and cell nucleus that solidify and shrink. At this stage, cells undergoing apoptosis shows a dark smeared core (core picnotic) are easily recognized by light microscopy (Junqueira and Carneiro, 2003).

In all groups of animals treated with stress, there are degeneration and necrosis cells. However the most severe degeneration is in the group treated with a single stress (Fig. $2 b)$. The amount of free radicals in the body attack the bio-macromolecules which is a component of the cell wall. As a result, the function of the cell wall is decreases cause the cell damage in the form of degeneration and necrosis as seen in the group treated stress (Anisman and Merali, 2009). Oxidative stress can result in damage to all molecular targets such as DNA, proteins and lipids (lipid peroxidation), which affects the tissue damage (Halliwell, 2001). 


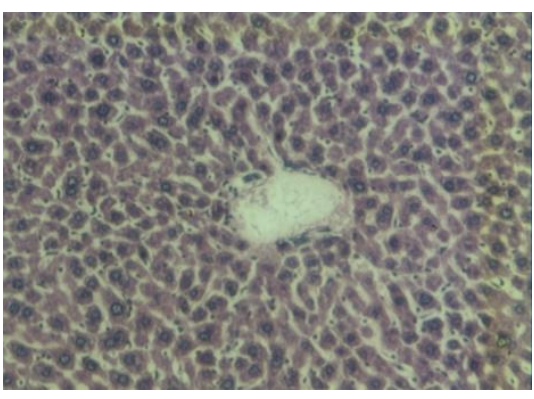

a

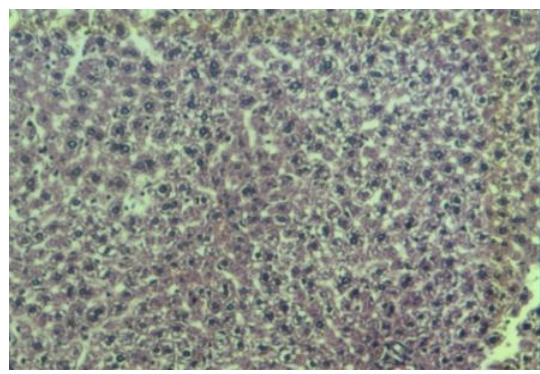

c

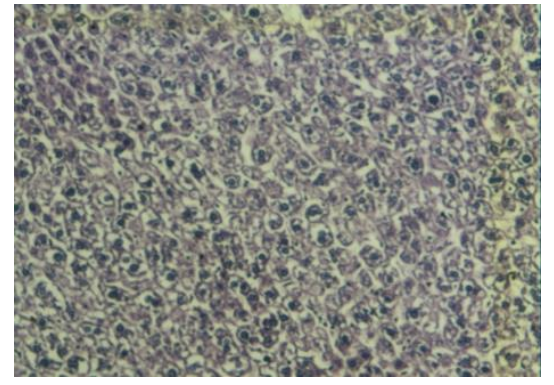

b

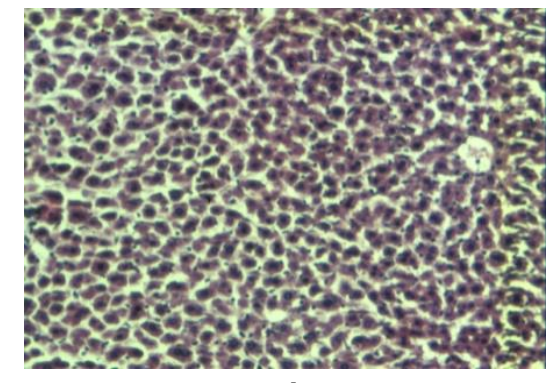

d

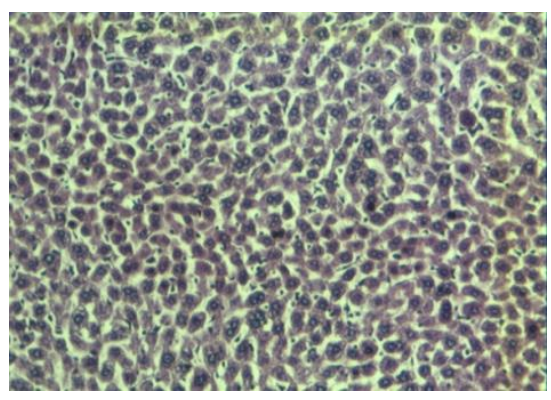

e

Figure 2. Overview of mice liver histology by Hematoxylin and Eosin staining on various treatments (magnification 10x). (a) Normal Group, (b) Stress Group, (c) Stress Group is treated with EEACL $50 \mathrm{mg} / \mathrm{kgbw}$, (d) Stress Group is treated with EEACL $100 \mathrm{mg} / \mathrm{kgbw}$, (e) Stress Group is treated with EEACL $150 \mathrm{mg} / \mathrm{kgbw}$.

\section{SOD examination}

The level of SOD examination was done qualitatively and quantitatively. Qualitative observations was done by observing the brown color intensity of the liver tissue after staining by immunohistochemistry with an antibody involving Zn-SOD (Fig. 3). The older of the brown color of the liver tissue indicate the higher of SOD content. Whereas the quantitative observations was done by counting the number of liver cell nuclei react to $\mathrm{Zn}$-SOD. Qualitative observations indicate a difference color intensity in each treatment group. The control group showed the highest intensity of the brown color and stress treatment group showed the lowest one. It suggests that stress induced by psychological stress in mice can increase free radicals and reduce levels of SOD. According to Wresdiyati (2012), a decrease in SOD activity caused by the heavier activity of the enzyme on treating of oxidative stress continuously.

Based on the results, it shows that a decreasing of SOD levels in all groups were given psychological stress compared to the control group were given normal (Fig. 4). 


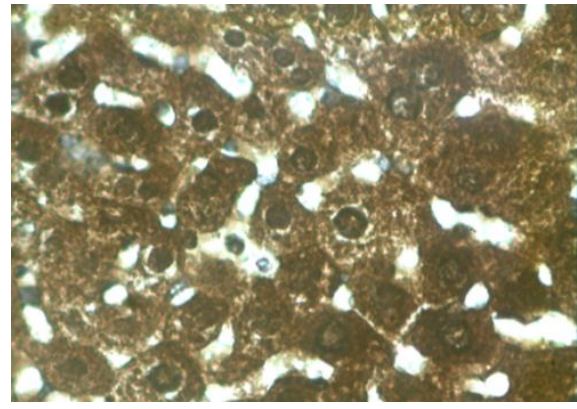

a

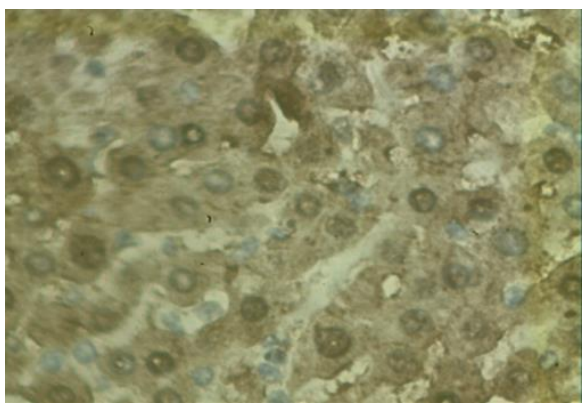

c

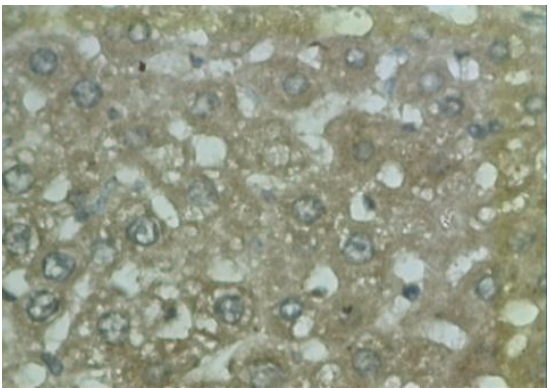

b

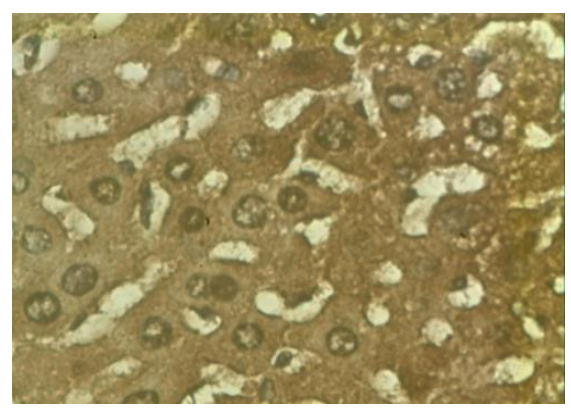

d

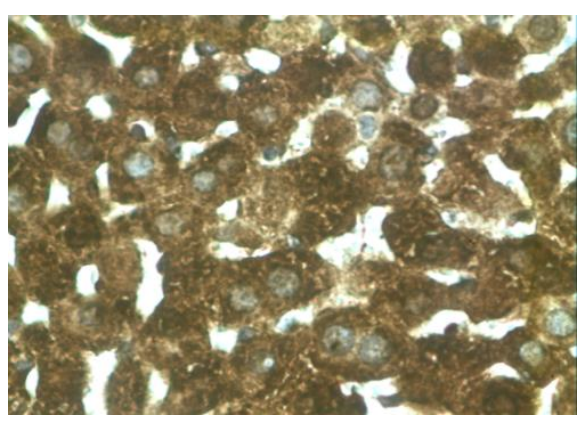

e

Figure 3. Overview of mice with liver histology immuno-histochemical staining Zn-SOD in various treatments. (a) Normal Group, (b) Stress Group, (c) Stress Group is treated with EEACL $50 \mathrm{mg} / \mathrm{kgbw}$, (d) Stress Group is treated with EEACL $100 \mathrm{mg} / \mathrm{kgbw}$, $€$ Stress Group is treated with EEACL $150 \mathrm{mg} / \mathrm{kgbw}$.

Table 2. The mean of reacted mice liver cel nuclei in various level of $\mathrm{Zn}$-SOD

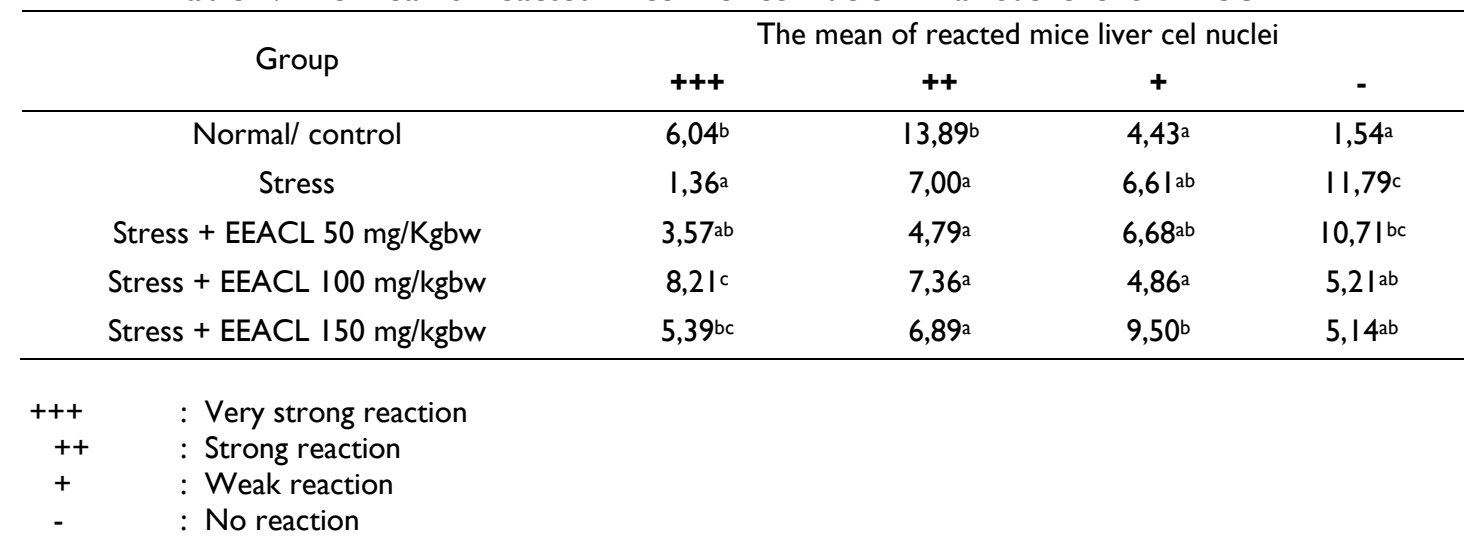




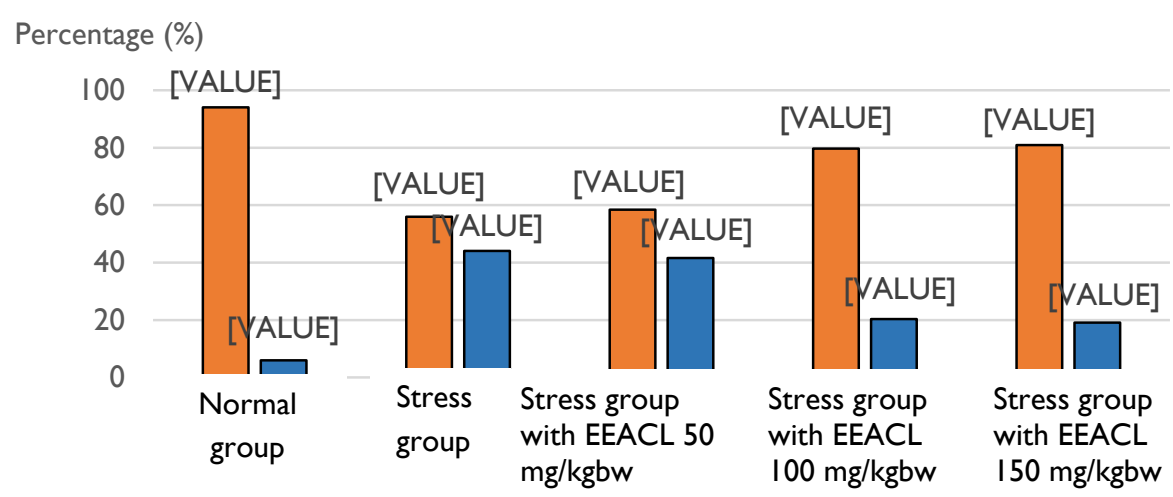

Figure 4. Graphic of percentage of nuclei cell ammount reacted positively dan negatively with Zn-SOD

This decline can clearly be seen mainly on the number of cell nuclei were strong positive reaction $(+++)$ and moderate positive $(++)$. Likewise, where an increasing number of cell nuclei that react negatively in all groups were given stress indicates an increase in free radicals. Psychological stress is given in the experimental mice can increase the production of reactive oxygen species (ROS), which is characterized by the occurrence of oxidative DNA damage of peripheral blood cells of the mice (Nishio, et al., 2007). Increased ROS can cause oxidative stress conditions which occur imbalance between free radicals with antioxidants, where the number of free radicals more than the antioxidant (Halliwell, 2006). Giving EEACL in group stress can reduce free radicals. This can be seen both qualitatively and quantitatively. Qualitatively, the effect on the decrease in free radicals EEACL characterized by decreasing color intensity with increasing doses network EEACL given. While the quantitative, the number of cell nuclei that react adversely diminishing with increasing dose. This can occur because EEACL contain polyphenol compounds such as flavonoids, which have antioxidant activity. EEACL known to have antioxidant activity which is categorized as very strong with $\mathrm{IC}_{50}$ value of $38.65 \mathrm{ug} / \mathrm{mL}$ so as to ward off free radicals (Marianne, et. al, 2011). Besides having a very strong antioxidant activity, EEACL also has a total phenol content is high enough $(235.03 \pm 4.306 \mathrm{mg} \mathrm{GAE} / \mathrm{g}$ extract) are suspected to have a role in enhancing the antioxidant activity.

Several studies have shown a strong correlation between total phenolic content and antioxidant activity. The higher the phenol content in a material, the higher the antioxidant activity. Flavonoids as antioxidants play a role in inhibiting the extracellular enzyme responsible for the production of superoxide anion radical $\left(\mathrm{O}_{2}{ }^{*^{-}}\right)$as xanthine oxidase and protein kinase $\mathrm{C}$. In addition, flavonoids also inhibit the enzyme cyclooxygenase, lipooksigenase, microsomal monooxygenases, glutathione S-transferase and NADH oxidase all involved in the formation of ROS (Pieta, 2000).

As with the effects of a decrease in free radicals, EEACL also have an effect in improving SOD enzyme. In the group given EEACL stress, tissue color intensity increased with increasing dose. Research conducted by Borra's (2006) proved that the isoflavones genistein, which is one class of flavonoids from soy bean able to defend-the SOD enzyme activity by inducing the genes responsible for the synthesis of the enzyme SOD. However, the unknown EEACL specific flavonoid compounds that have the effect of elevated levels of SOD. Quantitatively, the number of cell nuclei that react positively also increased with increasing dose. The effect of this increase is expected because flavonoids are potent antioxidants in EEACL not only neutralize free radicals that are formed as a result of stress but also may affect the activity of SOD enzyme. 


\section{CONCLUSION}

It can be concluded that the total phenols of Artocarpus camansi leaves extract has an influence to SOD levels. The increase of SOD levels is along with the increase of Artocarpus camansi leaves extract dose. The higher dose of EEACL leading to higher levels of SOD in the mice liver.

\section{REFFERENCES}

Anisman, H. and Merali, Z., 1999., Understanding Stress: Characteristic and Caveates, Alc. Res. Health., 23(4),24I-248.

Borras, C., Gambini, J., Cabrera, M.C.G., Sastre, J., Pallardo, F.V, Mann, G.E., et al, 2006, Genistein, A Soy Isoflavone, Up Regulates Expression of Antioxidant Genes: Involvement of Estrogen Receptor, ERKI/2 and NFkB, FASEB Journal, 20(I 2), |476-2 I 38.

Chida, Y., Sudo, N. and Kubo, C., 2006, Does Stress Excerbate Liver Diseases?, J. Gastroenterol. Hepatol., 2 I ( I), 202-208.

Gulcin, L., Uguz, M.T., Oktay, M., Beydemir, S. and Kufrevioglu, O.I., 2004, Evaluation of the Antioxidant and Antimicrobial Activities of Clary Sage (Savia sclarea L.), Turk. I. Agric. For., 28, 25-33.

Halliwell, B., 2006, Reactive Species and Antioxidants: Redox Biology is a Fundamental Theme of Aerobic Life, Plant Physiol., I4I(2), 312-322.

Halliwel, B., 200I, Free Radicals and Other Reactive Species Disease, In: Encyclopedia of Life Science, Chichester: John Wiley and Sons Ltd, p. I- 7.

Hilakivi-Clarke, L. and Dickson, R.B., 1995, Stress Influence on Development of Hepatocellular
Tumors in Transgenic Mice Overexpressing TGF-a, Acta Oncol., 34(7), 907-912.

Junqueira, L.C. and Carneiro, J., 2003, Basic Histology: Text \& Atlas, Tenth Ed., In: Tambayong, J., translator, 2003 Histologi Dasar: Teks \& Atlas, I0th edition, Jakarta: EGC Publisher.

Kregel, K.C. and Zhang, H.J., 2007, An Integrated View of Oxidative Stress in Aging: Basic Mechanisms, Functional Effects, and Pathological Considerations, Am. J. Physiol. Regul. Integr. Comp. Physiol., 292(I), RI8-R36.

Marianne, Yuandani, and Rosnani, 20I I, Antidiabetic Activity From Ethanol Extract of Kluwih's Leaf (Artocarpus camansi), Jurnal Natural, I I (2), 64-68.

Moein, S. and Mahmood, R.M., 2010, Relationship between Antioxidant Properties and Phenolics in Zhumeria majdae, J Med. Plants Res., 4(7), 5l7-52l.

Nishio,Y., Nakano,Y., Deguchi, Y., Terato,H,. Ide,H., Ito,C., et al., 2007, Social Stress Induces Oxidative DNA Damage in Mouse Peripheral Blood Cells, Genes Environt., 29(I), 17-22.

Pietta, P.G, 2000. Flavonoids as Antioxidants, J. Nat. Prod., 63(7), 1043-1046.

Rosidah, Yam, M.F. and Asmawi, M.Z., 2008, Antioxidant Potential of Gynura procumbens, Pharm. Biol., 46(9), 616-625.

Wiryanthini, D.I.A, Aman I.G.M, and Bagiada N.A, 2012, Pemberian Ekstrak Biji Kakao (Theobroma cacao I.) Menurunkan Kadar Malondialdehide dan Meningkatkan Kadar NOx Darah Tikus Putih (Rattus norvegicus) yang Diinduksi Stres Psikososial, Jurnal Ilmiah Kedokteran Medicina, 43, 47.

Wresdiyati, T., Astawan,M., Fithriani, D., Adnyane, I.K.M, Novelia,S. and Aryani, S., 2009., Pengaruh $\alpha$-Tokoferol terhadap profil Superoksida Dismutase dan Malondialdehida pada jaringan Hati Tikus di Bawah Kondisi Stress, Jurnal Veteriner, I 0(2), 202-209. 